\title{
Symmetrical flap technique for anterior capsulorhexis
}

\author{
Sudarshan Khokhar, Saumya Kumar, Avilasha Mohapatra
}

Ophthalmology, All India Institute of Medical Sciences, New Delhi, Delhi, India

\section{Correspondence to}

Dr Saumya Kumar; saumya1953@gmail.com

Accepted 15 March 2021

\section{DESCRIPTION}

The initial technique of making the opening in anterior capsule was first given by Gimbel, Shimizu and Neuhann in $1990 .{ }^{1}$ They named the technique as 'continuous curvilinear capsulorhexis' or 'CCC'. CCC provided various advantages such as better intraocular lens (IOL) stability, and no ' $\mathrm{v}$ '-shaped tears with tendency of extension and preservation of sulcus for IOL placements in cases of posterior capsular defects. However, making an adequately sized circular capsulorhexis without the help of devices like zeptorhexis, ${ }^{2}$ femtolaser-assisted cataract surgery, manual marking on cornea and so on, remains a challenge. ${ }^{3}$

We would like to describe a new 'symmetrical flap technique' for capsulorhexis. It is an inexpensive non-machine or device-dependent technique. Steps for this technique (video 1) are as follows: first, we make clear corneal incision with microvitreoretinal surgery blade (MVR) at the site of our main incision. Then the anterior chamber is filled with hydroxypropyl methyl cellulose (HPMC). A 26-gauge needle cystotome attached to partially filled viscoelastic syringe is introduced through MVR entry and a radial nick is given on the anterior capsule from centre to periphery of approximately $2 \mathrm{~mm}$ in length. A flap is everted using the cystotome needle and is put flat over the anterior capsule. The everted flap should be laid completely flat on anterior capsule such that margins of everted flaps and cut margin of anterior capsule are mirror image of each other (figure 1). The curvature of everted flap acts as a guide to create the circular capsulorhexis. Capsulorhexis is completed by pulling the flap tangentially along its own curvature and completed by joining to the point of start of rhexis.

Viscoelastic used to form the anterior chamber should have a low viscosity to keep the everted flap flat. As we are using a cystotome from a small incision, HPMC is sufficient to maintain the chamber while doing the capsulorhexis. It was observed that if higher viscosity ophthalmic viscosurgical devices

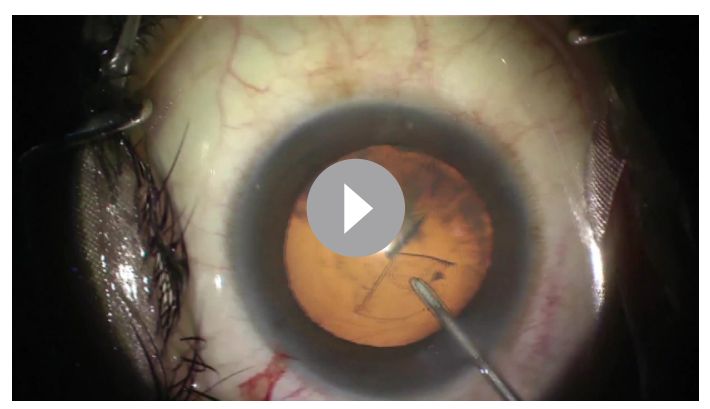

Video 1 Surgical video demonstrating the symmetrical flap technique

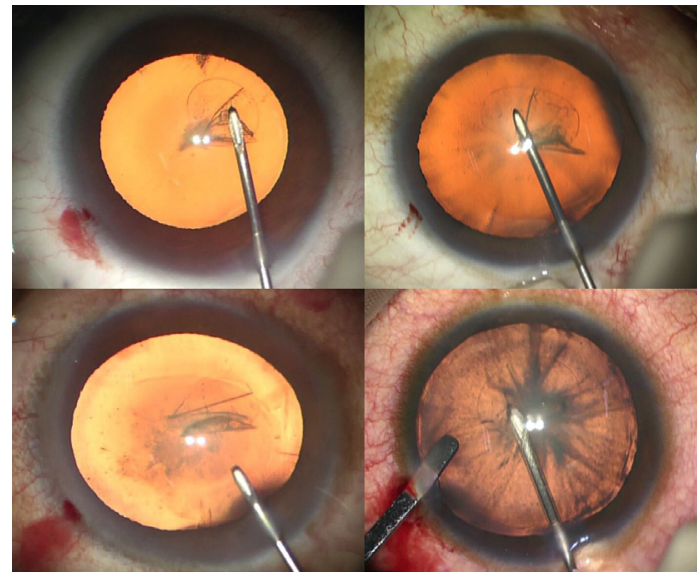

Figure 1 Intraoperative picture under retroillumination of operative microscope showing the everted capsulorhexis flap which is a mirror image of cut margin of anterior capsule in four different patients.

(OVDs) are used such as Healon or Healon GV in this technique, it causes difficulty in flattening the flap. Using HPMC also reduces the surgical cost. ${ }^{4}$

Forceps capsulorhexis is also a good method to make a circular capsulorhexis, but it also has its own disadvantages. Forceps capsulorhexis uses a larger incision and requires a high-viscosity OVD to maintain the anterior chamber thereby increasing the surgical cost. Also, repeated leak of OVD from larger incision leads to shallowing of anterior chamber and need for multiple times injection of OVD increasing the surgical time. ${ }^{5}$

Although many surgeons prefer using forceps, this technique is highly advantageous for surgeons preferring needle cystotome. The various advantages of this technique are it does not require any additional equipment, it is highly cost-effective, it gives us a well-centred circular adequate size

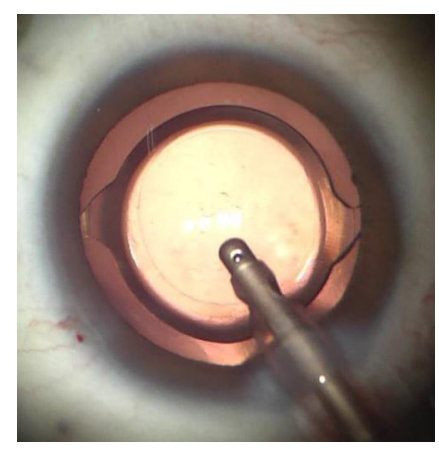

Figure 2 Intraoperative picture under retroillumination of operative microscope showing a well-centred circular capsulorhexis covering $0.5 \mathrm{~mm}$ of posterior chamber intraocular lens all around. 
capsulorhexis and it has minimal chances of outrunning of capsulorhexis (figure 2).

\section{Learning points}

It is an inexpensive technique to get a circular capsulorhexis. - This technique has less chances of outrunning of rhexis.

Contributors SuK did the surgery and contributed to the concept. SaK prepared the manuscript. AM did the video editing and retrieval.

Funding The authors have not declared a specific grant for this research from any funding agency in the public, commercial or not-for-profit sectors.

Competing interests None declared.
Patient consent for publication Obtained.

Provenance and peer review Not commissioned; externally peer reviewed.

\section{REFERENCES}

1 Gimbel HV, Neuhann T. Development, advantages, and methods of the continuous circular capsulorhexis technique. J Cataract Refract Surg 1990;16:31-7.

2 Pandey SK, Sharma V. Zepto-rhexis: a new surgical technique of capsulorhexis using precision nano-pulse technology in difficult cataract cases. Indian J Ophthalmol 2018;66:1165-8.

3 Thompson VM, Berdahl JP, Solano JM, et al. Comparison of manual, femtosecond laser, and precision pulse capsulotomy edge tear strength in paired human cadaver eyes. Ophthalmology 2016:123:265-74.

4 Arshinoff SA, Norman R. Tri-soft shell technique. J Cataract Refract Surg 2013;39:1196-203.

5 Dada T, Sethi H. Forceps capsulorhexis. J Cataract Refract Surg 2002;28:1491.

Copyright 2021 BMJ Publishing Group. All rights reserved. For permission to reuse any of this content visit

https://www.bmj.com/company/products-services/rights-and-licensing/permissions/

BMJ Case Report Fellows may re-use this article for personal use and teaching without any further permission.

Become a Fellow of BMJ Case Reports today and you can:

- Submit as many cases as you like

- Enjoy fast sympathetic peer review and rapid publication of accepted articles

- Access all the published articles

Re-use any of the published material for personal use and teaching without further permission

Customer Service

If you have any further queries about your subscription, please contact our customer services team on +44 (0) 2071111105 or via email at support@bmj.com.

Visit casereports.bmj.com for more articles like this and to become a Fellow 